\title{
NIGERIAN TELEVISION DRAMA SERIES AND AUDIENCE REACTIONS: A SEISMOLOGY EVALUATION
}

\author{
Stanislaus Iyorza ${ }^{1}$, Patience $\mathrm{Abu}^{2}$ \\ ${ }^{1,2}$ Department of Mass Communication, University of Calabar, Nigeria \\ stanisiyorza@unical.edu.ng ${ }^{1}$, kommyabu@gmail.com ${ }^{2}$
}

\begin{abstract}
The objective of this study is to find answers to evaluate reactions of the audience to the Nigerian television drama series in Nigeria, giving attention to how the programmes are making waves and the extent to which the audience has invested their knowledge, time and interest in them. Seismology is the study of effects or waves created by a dramatic piece, the entire theatrical event or radio or television programme. This discourse assumes that the Nigerian television drama series may not be evoking the desired reactions from their audience. The problem of this study is the uncertainty surrounding the impact or waves made by the Nigerian television drama series on their audience. To achieve the objectives of this study adopted quantitative and qualitative research methods to elicit audience reaction. The study employed the survey method using questionnaire and online interview designs to elicit responses on audience responses to Nigerian television drama series. Findings revealed that more than $80 \%$ of Nigerians watch at least one or more Nigerian television drama series out of interest. Audience reactions to the programmes are in form their expressions of knowledge about the drama series in terms of best actors, producers and television drama series in Nigeria. The audience also reacted that the Nigerian television drama series is more entertaining than educational and informational, even though some combine all those qualities. The audience also agreed that the Nigerian television drama series reflect life in Nigeria by promoting good morals and criticizing anti-social behaviours like raping, drug abuse and kidnaping. The paper recommends multinational companies' continuous sponsorship of television drama series that is targeted at making the Nigerian society a better place.
\end{abstract}

Keywords: Audience, Drama, Nigeria, Reactions, Seismology, Series, Television.

\section{INTRODUCTION}

The scramble for consumers of goods and services by multinational companies including Unilever, Nestle, Cadbury, MTN, Airtel and many Pharmaceutical industries in Nigeria, like other countries, is on the rise. This is evident in the companies' sponsorship of adverts featured amidst the transmission of television series. Some multinationals like Airtel and MTN (telecommunication giants) in Nigeria even sponsor more than two television series besides other radio and television programmes. Like a bride seeking to attract her suitors, producers of the Nigerian television soaps and series seek to attract their sponsors by proposing captivating storylines. Belch and Belch (2001:206) state that the marketing/public relations departments of the multinational companies assess proposals to sponsor television series if the proposed media of transmitting the programmes have the desired reach, if the proposal has the appropriate target audience for advertising the companies' goods or services and if the proposed series tend to gain popularity among the audience of the programme.

Many traditional media of communication such as radio, television, newspapers, magazines and billboards have presented publicity opportunities for producers of television series to publicize their programmes even though they hardly exhaust other avenues apart from television and scarcely radio (Iyorza 2017; Augoye, J. 2019; Beal, V. 2020). Sadly, most of the popularity of most Nigerian television drama series has been evaluated based on their presence in few media adverts by the satellite channels and also unconscious communications of the programmes by few viewers through word-of-mouth. This implies 
that most Nigerian producers of television series make little or no effort at giving their programmes the massive awareness and popularity required to attract more viewers and develop a wide audience base to attract sponsorship from the available multinationals (Burton, G. 2010; Chien, L. 2015; Encyclopedia Britannica 2003; Gitelman, L. and G.B. Pingree 2003; Hasan, S. 2003).

The need to expose the Nigerian television drama series to the interest of the viewing audience the world over through different means of communication, paid or not paid for, has attracted an evaluation of seismology in this paper. By implication, seismology is a very useful metaphor for the kind of study in which a media researcher with an interest in the impact of media programmes on society at large might engage, and would surely be seeking to promote and measure the social vibrations or oscillations caused by a media programme (a cultural explosion, shift or upheaval) within a specific community or society. As a field of study, relating to media, Hauptfleisch (2007:253) views seismology as a superfluous means of awareness creation of media programme and the impact thereof; the communication of artistic and the public interface including the way programme "messages" are disseminated beyond the immediate audience.

Common among some contemporary Nigerian television series include programmes like My Siblings and I, Hustle, Do Good, Tinsel, The Johnsons, My Flat Mates, Halita and Jimeji. Observably, television series appears to be a limited responsibility of media vehicles that host the programmes. DSTV, GOTV and Startimes are among the media vehicles on satellite that transmit Nigerian drama series. They advertise some programmes on their own, either independently at prime time or intermittently during the broadcast of the soaps (ITS. MARC,2018; Willie, A. 2018). Thus, the producers of the television series are hardly involved in the seismology of their programmes yet they desire the television series to be marketed amidst stiff viewership competition with other television soaps even on the same satellite stations Lievrouw, L. \& S. Livingstone 2002; Manovich, L. 2002; Merab, Y. E. 2015; Nwamuo, C. 2006; Okpara, G., Anyanwu, A. \& Inyanga, J. 2013; Raman, M. \& Singh, P. 2006; Shearer, P. 2009; Titchener, C. 1998)

The implication is the evolving questions of how publicized and popular are the Nigerian television series to attract viewership in Nigeria and beyond and what is the audience reaction to the series. It is on record that some of the old Nigerian television series that were famous and popular, such as Zebrudiah, Samanja and Jagua with captivating and hilarious themes and storylines went into extinction partly because of the dearth of seismology and later the divided interest of the cast and desire of the cast to seek greener pastures in other television series and movies. The whole development questions the seismology of Nigerian television series.

A seismological evaluation of television drama series and audience reaction is examined within the framework of one theory: The Uses and Gratification Theory. Ike (2005) explains that Uses and Gratification Theory, introduced by J.G. Blumber and E. Katz in 1974, anchors its strength on the fact that television audiences prefer programmes that best fulfill their desires. The theory argues that media audiences are not just passive but active participants who consciously choose the media programme that meets their needs. By extension, the media programme that intends to make waves must compete for the audiences' attention and it is only through the audience reaction that one can get to know if the television programmes are actually making waves. This also means that the television audiences are in the best position to determine the extent to which drama television series make waves because they choose which programme and content to see 


\section{Jurnal Sosialisasi \\ Jurnal Hasil Pemikiran, Penelitian, dan Pengembangan \\ Keilmuan Sosiologi Pendidikan \\ Vol 7, Nomor 2, Juli 2020}

and decide which product is best for them. The main challenge of the theory is that all audiences may not find the same programmes useful and gratifying.

This discourse assumes that the Nigerian television drama series may not be making the desired impact on their audience. The problem of this study is the uncertainty surrounding the impact or waves made by the Nigerian television drama series on their audience. The problem is complicated when considered in line with the fact that various multinationals and other sponsors spend heavily to sustain the programmes through intermittent commercials. The objective of this study is to find answers to the following research questions: What are the reactions of the audience in the Nigerian television drama series? How are the Nigerian Television drama series evoking waves among their audience? To what extent are the audiences interested in the Nigerian television drama storylines and ensemble?

\section{METHOD}

A seismology evaluation of Nigerian television drama series required discovery and assessment of waves made by the media programmes understudy and as such the study adopted quantitative and qualitative research methods to elicit audience reaction. The study employed the survey methods using questionnaire and online personal communication designs to elicit responses on audience responses to Nigerian television drama series. Respondents to questionnaire were made up of 480 randomly selected persons from the Cross River State capital, Calabar in Nigeria. The choice of area of study was for no special reason other than the researchers' proximity to the study population. The online interview on the other hand involved 14 randomly selected viewers (the target audience) of the Nigerian television drama series and interaction with them was carried out using social media platforms, specifically Facebook, Whatsapp and E-mail. The ages of both participants and respondents were pegged at 16 years and above. This was taken into consideration because most of the drama series is targeted at the population within that age. The questionnaire was designed to confirm the viewing status of the target audience and their interest in the drama series. The online interview questions were designed to elicit audience reactions (opinions on lessons drawn from the Nigerian television drama series, choice of best Nigerian television drama series, best actors and their overall interest and knowledge of the themes, settings and producers of the Nigerian television drama series). On the whole, a total population of 494 participants and respondents featured in this research.

\section{RESULT AND DISCUSSION}

\section{Presentation of Findings from Questionnaire}

The essence of a quantitative study was necessary to validate the audience's qualifications for this study. Five hundred persons age 16 years and above were earmarked for this study but only 480 respondents who returned their copies of the questionnaire finally participated. Findings revealed that all respondents had seen or followed at least one or more Nigerian television drama series but not all respondents have been audience to all series at the same time. This is obviously because the television drama series have different themes and storylines in line with the different interest of the heterogeneous audience. 
Table 1

Indication of Audience Interest in Nigerian Television Drama Series

\begin{tabular}{|c|c|c|}
\hline Interest of Audience & Frequency & Percentage (\%) \\
\hline $\begin{array}{c}\text { Nigerian audience following television drama series } \\
\text { with interest }\end{array}$ & 374 & 78 \\
\hline $\begin{array}{c}\text { Nigerian audience without an interest in television } \\
\text { drama series }\end{array}$ & 106 & 22 \\
\hline Total & $\mathbf{4 8 0}$ & $\mathbf{1 0 0}$ \\
\hline
\end{tabular}

Source: (Field Survey, February 2020)

To validate the interest of participating audiences, the table I above shows that more Nigerians $(78 \%)$ have an interest in the viewership of Nigerian television drama series while fewer Nigerians $(22 \%)$ do not have an interest in the programmes. Findings revealed that the audience with interest found out about their favourite television drama series by searching for programmes on their satellite stations, by discussing with their friends or siblings and through exposure to information about their favourite television drama on other media of communication. Participants for the qualitative study (interview) were selected from respondents who were found to have an interest in the Nigerian television drama series.

\section{Presentation of Findings from Online Interview}

a. Audience reaction to point of interest in the Nigerian television drama series

From the reactions of the respondents, the entertainment aspect constitutes the main point of audience interest in the Nigerian Television drama series, followed by the informational and the educational. Statistically, the entertainment element constitutes $60 \%$ of the interest factor while informational and educational aspects share $40 \%$ (20\% each). The evidence that the audience show interest in the Nigerian television drama series is an indication that the programmes have gained the required publicity and made the desired gain that will help sponsors continue to patronize the creative works to market their goods and services. Specifically, Victoria Sunday (personal communication, 2020), an entrepreneur in Lagos State indicated an interest in the Nigerian television drama series ability "to point out societal ills such as rape and prostitution and the need to desist from them". The series also interestingly reflect problems of declining morals among Nigerian families and the need to derive notable lessons.

b. Audience reaction to lessons drawn from the choice of various Nigerian television drama series

Audience reaction also indicates that viewers of Nigerian television drama series significantly benefit life lessons from the programmes. Participants have enumerated lessons derived from the television series to include the negative effect of greed, the best ways to choosing life partners and ways of taking courageous steps to bring about positive change with individual efforts. Other lessons from the programmes are pitched on the dangers of domestic violence, response to rape attempts, implications of pretense, steps to survival strategies and ways of firm submission to high moral standards in the society (Udoudom et al., 2018; Ogar et al., 2018). Mrs Gladys Ekpo (personal communication, 2020) says "I have learnt not to be greedy in the TV Series Hotel Majestic". Elizabeth Johnson (personal communication, 2020) says she has learnt how to do "what is right" and has learnt from "others' mistakes in life". The audience's reaction to an extent of stating the 
main lessons derived from the ideas of the Nigerian television drama series is an indication that the Nigerian television audience responds appropriately to the themes of the television series.

c. Audience reaction to the choice of best character (actor or actress) and knowledge about producers of some very interesting Nigerian television drama series

Seismology is also measured based on how much the audiences know about the cast and their opinion about them. Participants displayed knowledge about some of the actors and actresses whom they also rated as the best among Nigerian television drama series. Some of the names identified by the audience include Charles Inojie, Seun Ajayi and Mary Remmy Njoku. Others include Timini Egbuson, Lota Chukwu, Kate Henshaw, Adebukola Oladipupo, Mary Remmy Njoku, Raymond Asuquo, Bright Okpocha, Hilda Dokubo and Sodima Anyama. The audience also demonstrated substantial knowledge about the producers of some of the famous Nigerian television drama series. Participants identified producers like John Njamah, Mary Remmy Njoku, and Tope Oshin. Others include Funke Akindele Bello, Adebukola Oladipupo, Rogers Ofime, Funke Akindele, Rogers Ofime, John Njamah and James Omokwe.

$d$. Audience reaction to knowledge about the objective $(s)$ of the Nigerian Television drama series

Members of the audience reacted impressively to the quest for knowledge about the mission of the Nigerian television drama series. Some say the objective of some of the series from their perspective is to entertain, to inform and to educate. From the choice of her best Nigerian television series, Catherine Bassey (personal communication, 2020) says she learns from the television drama series "how rough the streets can be". With reference to The Johnsons, which she considered as one of her best, Victoria Sunday says the essence of the Nigerian television drama series "is to let married couples who are going through such dramas in their marriage to know how to handle such situations because at the end no marriage is perfect and it's all about the understanding". Mary Imbufe (personal communication, 2020) states:

The essence of Tinsel is to show what goes on in the music industry or even our daily politics and how the quest for dominance leads to so many wrong deals and doings. Tinsel is an all-round drama series which comprises of Wealth, Fame, Love, and Rivalry. (Online Group Discussion, 2020)

Most of the respondents express the opinion that the Nigerian television drama series are targeted at strengthening family ties and drive home some very important life lessons using humour. Elizabeth Johnson (personal communication, 2020) says the objective of the drama series is to project "positive information about a typical average Nigerian family, for instance, the lead character in The Johnsons encourages the Nigerian youths in his role never to give up". This is an indication that the seismology of the Nigerian television drama series is valid.

e. Audience reaction to interest in further studies and choice of best Nigerian television drama series

A total of $60 \%$ of the online participants go a step further to read more about the drama series from sources such as the blogs from the internet and watch documentaries on the drama series on Channels television. However, studies showed that about $40 \%$ of the audience does not bother to read out more information about the programmes apart from discussing them with their friends. About $60 \%$ of the online participants chose The 


\section{Jurnal Sosialisasi \\ Jurnal Hasil Pemikiran, Penelitian, dan Pengembangan \\ Keilmuan Sosiologi Pendidikan \\ Vol 7, Nomor 2, Juli 2020}

Johnsons as their best and most interesting Nigerian television drama series, followed by Tinsel, Ajoche, My Siblings and I, Battle Ground and My Flatmates.

f. Audience reaction to the choice of best Nigerian television drama series with the most appealing setting (the time when and place where the drama actions take place) and the most appealing and intriguing storylines relevant to moral or social wellbeing.

The audience also showed deeper knowledge of the Nigerian television drama series with the most appealing setting. Participants' responses include Battleground, My Siblings and I, Hush, The Johnsons, My Flatmates and Hustle. A few participants were however indecisive and commented that it was difficult to say which programme had the most appealing setting. In terms of most appealing and interesting storylines, $70 \%$ of the audience chose My Siblings and I first, followed by Ajoche, Jennifa's Diary and The Johnsons, Tinsel and My Flatmates.

g. Audience reaction to the choice of Nigerian television drama series with the best set of actors that reflect people and their behaviour in modern times

Audience reaction shows that Jenifa's Diary is the most preferred Nigerian television drama series with the best set of actors that reflect people and their behaviour in modern times. Some participants were indifferent about the question of the best set of actors. Victoria Sunday says "The ones I have watched have very good actors who bring out the essence of what the drama is all about and therefore making each scene they act appealing and interesting." Mary Imbufe (personal communication, 2020) comments that: "it is really difficult to ascertain which particular drama series have the best set of actors. The ones I have watched so far are not doing poorly." Others responded that Ajoche, My Flatmates and The Johnsons have a good set of actors too.

From the foregoing, the Nigerian television drama series are not adequately publicized but Nigerian audiences have been exposed to them through mere searching of the satellite television channels. A few audiences have been lured into watching them from attractive discussions of the drama series with their friends and siblings. This violates the essence of seismology as an organized effort made by the producers of the television drama series to lure the potential and target audience into watching the programmes. However, without the normal advertisements or publicity strategies, studies reveal that seismology can occur as an unconscious effort if, through simple information transmission at the interpersonal and group communication levels, the potential audience can identify what informational, educational and entertainment benefits to derive from the programmes.

Study reveals that close to $80 \%$ of Nigerians watch at least one of the many Nigerian television drama series. Others even follow more than one of the series. However, seismology evaluation is not only about determining how many viewers watch a television programme but also how many watch with interest. Audiences' interest in a television programme is measured by their knowledge, assessment and preferences for specific television drama series. Their interest is also measured by their emotional attachment to the theme of each television series and their willingness to find out more about stories and characters or producers of their choice. This is exemplified by the participants' response to the Nigerian television drama series, specifically those that are adjudged by bloggers and award institutions in the country as the most thrilling at the moment.

From the audience reactions, the Nigerian television drama series are communicators of lessons in life, reflectors of ills in the Nigerian society and critics of anti-social behaviours including rape, kidnapping and other social vices in Nigeria. More fundamentally, the drama series are definitive examples of 'edutainment' and 'infotainment' 


\section{Jurnal Sosialisasi \\ Jurnal Hasil Pemikiran, Penelitian, dan Pengembangan \\ Keilmuan Sosiologi Pendidikan \\ Vol 7, Nomor 2, Jufi 2020}

- postmodern terms used to describe artistic pieces that contain elements of education and entertainment or information and entertainment (Yta 2017). However, the Nigerian audiences are of the view that the drama series is more entertaining in the course of promoting good moral and criticizing vices in the society (Iyorza 2013; Iyorza 2017b).

Audience reaction has also indicated that there are best Nigerian actors, actresses and producers in the Nigerian television drama series. The audiences' ability to mention the likes of Charles Inojie, and Kate Henshaw as some of the best actors and John Njamah and Funke Akindele Bello as some of the best producers in the Nigerian television drama series shows that the programmes are already making waves among all categories of the Nigerian audience. The audience has shown that they appreciate the entertaining, educational and informational nature of the storylines blended with the appropriate setting and have identified Jenifa's Diary, My Siblings and I, Ajoche, My Flatmates and The Johnsons are among the best Nigerian television series with the best and most appropriate actors. The ability of the audience to discuss the best Nigerian television series is an indication that the programmes are successful and significantly making waves in the country. This has validated the Uses and Gratification Theory but has challenged the theory's total efficacy where interest to a particular programme varies because of the heterogeneous nature of the audience.

\section{CONCLUSION}

Although some of the drama series is currently experiencing time out owing to the Covid-19 pandemic and other reasons, the already projected series have made the waves desired. Producers should not relent but continue to produce more interesting series to sustain the Nigerian audience at home and in the diaspora. With such captivating storylines, multinationals and sponsors such as Airtel and Dano Milk should continue to support the producers with the required advertising funds so that the lessons and points of interest enjoyed by the Nigerian audience will not fade away. Sponsors should give producers of the Nigerian television drama series longer contract to enable them to enjoy a longer life span that will keep Nigerians informed, educated and entertained. This can save the country a lot of lives that would have spent time contemplating suicide due to harsh economic crises. The producers of the television drama series should remunerate the cast and crew of their productions handsomely to sustain a more professional team for a long time. This will save the productions some distractions of searching for more lucrative contracts in other productions.

\section{REFERENCES}

Augoye, J. (2019) "Five Nigerian TV series that held us spellbound in 2019" Premium Times. https://www.premiumtimesng.com/ Retrieved $31^{\text {st }}$ May 2020

Beal, V. (2020) New media. https://www.webopedia.com

Belch, G. \& Belch, M. (2001) Advertising and promotion: an integrated marketing communication perspective. $5^{\text {th }}$ edition Boston: McGraw-Hill.

Burton, G. (2010) Media and society: critical perspectives. $2^{\text {nd }}$ edition. Berkshire: McGraw-Hill.

Chien, L. (2015) "What is the difference between Tv series and Tv shows?" Quora. https://www.quora.com. Retrieved $31^{\text {st }}$ May 2020.

Encyclopedia Britannica. (2003) $15^{\text {th }}$ edition. Vol. 16 "Seismograph" and "Seismology" pp 489491.

Gitelman, L. and G.B. Pingree (2003). 'What's new about new media?' New media. Cambridge, MA: MIT Press. 
Hasan, S. (2003) Mass communication: principles and concepts. $2^{\text {nd }}$ edition. New Delhi: CBS.

Hauptfleisch, T. (2007) "The Seismology of Theatre: Tracing the shocks waves of a Theatrical event in society". South African theatre journal Vol 21: pp 253-271.

Ike, N. (2005) Dictionary of mass communication. Owerri: Book-Konzult.

ITS.MARC (2018) Definition: Television Series. https://www.itsmarc.com. _Retrieved $31^{\text {st }}$ May 2020

Iyorza, S. (2013). Quality Issues and the Ban on Selected Musical Video Broadcasting In Nigeria: A Defence for the National Broadcasting Commission ( $\mathrm{Nbc}$ ). Nigerian eatre Journal.

Iyorza, S. (2017). Nollywood in Diversity. International Journal of communication: an interdisciplinary Journal of communication Studies, 21(2).

Iyorza, S. (2017). Nollywood in Diversity: New Dimensions for Behaviour Change and National Security in Nigeria.

Law Insider Inc. (2020) 'Definition of television series'. Law insider dictionary https://www.lawinsider.com. Retrieved $31^{\text {st }}$ May 2020.

Lievrouw, L. \& S. Livingstone. (2002). 'Introduction: the social shaping and consequences of ICTs' Handbook of new media. CA: Sage Publishers.

Manovich, L. (2002). 'New media from borges to HTML' in Wardrip-Fruin and N. Montfort (eds.), The new media reader. Cambridge, MA: The MIT Press.

Merab, Y. E. (2015). Changing Trends in Dreamboat Children's Theatre, Calabar, Nigeria. Indian Journal of Applied Research 5 (8), 582-586

Nwamuo, C. (2006) Theatre audience engineering in Nigeria: paradigm and syntagm._Calabar: University Press.

Ogar, J. N., Idagu, U. A., \& Bassey, S. A. (2018). Ethics in a technological society. Journal of Sustainable Society, 7(1), 1-4.

Okpara, G., Anyanwu, A. \& Inyanga, J. (2013) Marketing communications. Owerri: Avan Global.

Raman, M. \& Singh, P. (2006) Business communication. Oxford: University Press.

Shearer, P. (2009) Introduction to seismology. Cambridge, University Press.

Titchener, C. (1998). "Television; the awesome medium" Reviewing the arts. New Jersey: LEA Communications.

Udoudom, M. D., Idagu, U. A., \& Nwoye, L. (2018). Kantian and Utilitarian Ethics on Capital Punishment. Journal of Sustainable Society, 7(1), 5-11.

Willie, A. (2018) 10 top Nigerian series https://connectnigeria.com Retrieved $31^{\text {st }}$ May 2020

Yta, E. M. (2017). Using identification in entertainment-education drama serials to promote women's rights in Cross River and Akwa Ibom States. Lwati: A Journal of Contemporary Research, 14(4), 301-320. 